\title{
Long-term dynamics and spatial distribution of stable and labile components in ground beetle communities (Coleoptera: Carabidae) in a mosaic of flood-plain meadows
}

\author{
OLGA S. TRUSHITSYNA ${ }^{1}$ \\ ANDREY V. MATALIN2,4 \\ KIRILL V. MAKAROV ${ }^{3}$ \\ ${ }^{1}$ The S. Yesenin Ryazan State University \\ Research Laboratory of Evolutionary Ecology \\ Svobody Str. 46, Ryazan 390000, Russia \\ trushicina01@mail.ru \\ ${ }^{2}$ Moscow State Pedagogical University \\ Education and Scientific Centre of Ecology \\ \& Biodiversity, Kibalchicha Str. 6, BId. 5 \\ Moscow 129164, Russia \\ andrei-matalin@yandex.ru \\ ${ }^{3}$ Moscow State Pedagogical University \\ Biology \& Chemistry Institute \\ Zoology \& Ecology Department, Kibalchicha Street 6 \\ Bld. 5, Moscow 129164, Russia \\ kvmac@inbox.ru \\ ${ }^{4}$ The N.I. Pirogov Russian National Research \\ Medical University, Department of Biology \\ Ostrovitianova Str. 1, Moscow 117997, Russia

\section{Correspondence:} \\ Andrey V. Matalin \\ E-mail: andrei-matalin@yandex.ru
}

Key words: carabids, Russia, Oka River, pitfall trapping, meadows, dominance structure, stable-labile component, migrations

Received January 26, 2016.

Revised June 16, 2016.

Accepted July 8, 2016

\begin{abstract}
Background and purpose: Long-term changes in the community structure of ground beetles were surveyed in nine flood-plain meadows of the Oka River valley (Ryazan Region, Russia) using the concept of stable-labile components. Such approach contradicts with the traditional estimation of the community structure, and there are only a few similar studies now.
\end{abstract}

Material and methods: Based on inundation time, all model habitats were divided into three groups: dry, short-term flooded, and long time flooded meadows. Beetles were trapped from mid-April to late September 2006 and from early April to late October in 2007 and 2008 using pitfall traps. All captured beetles were dissected and the conditions of their gonads were evaluated.

Results and conclusions: Altogether, 142 species from 50 genera were recorded. In terms of abundance, $84 \%$ of all specimens belonged to 22 species (15.5\% of the total species diversity). However, neither in all years nor in all study habitats the local populations of dominant species are characterized by a complete demographic structure. On the contrary, 49 species were residents, but only from three to 27 of them completed their life cycles at least in one habitat. In total, the labile component usually had a higher species diversity, but the stable component was more abundant. Large-scale migrations were typical solely of stenotopic species that inhabit only few meadow types. Eurytopic species were easy to redistribute in a limited area and occupied all available habitats. In some species, not only migrations, but also changes in life cycles from annual to biennial ensured the survival of their local populations.

\section{INTRODUCTION}

Clood-plain meadows are among the best-known unstable and vari-

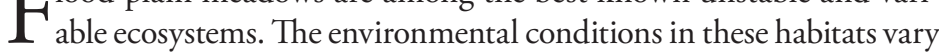
annually under changing weather parameters and hydrological regimes (1), and significantly affect the abundance and distribution of terrestrial arthropods $(2,3)$.

It is noteworthy that annual fluctuations of the environmental conditions in flood-plain meadows can render a strong impact on the dynamics and activity of certain ground beetle species (Coleoptera: Carabidae), their spatio-temporal distribution, as well as on the structure of the community as a whole $(4,5,6,7,8,9,10)$. 


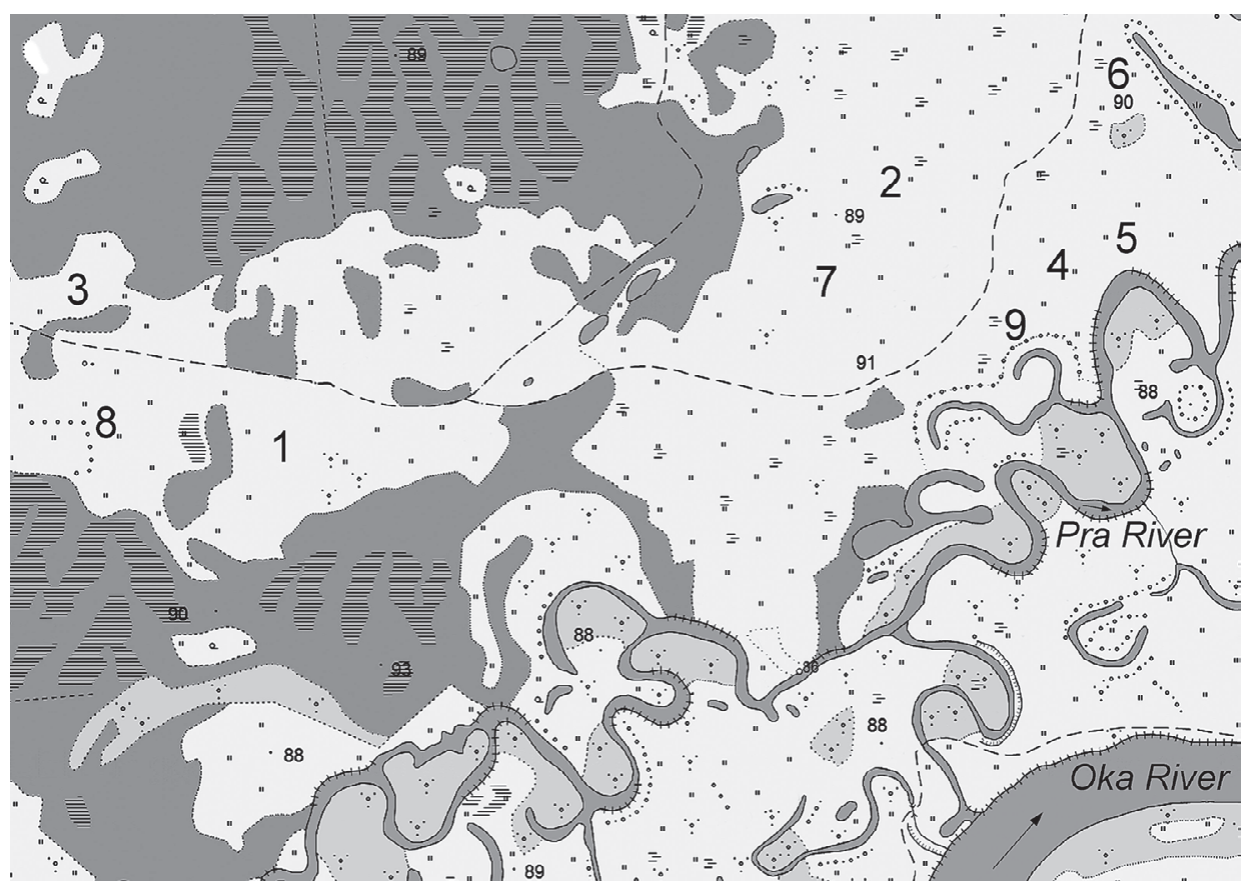

Figure 1. Study area (habitats as in Table 2).

This paper deals with the community structure of $\mathrm{Ca}$ rabidae in different types of flood-plain meadow using the concept of stable-labile components (11). The main point of this concept is that the regular change in the physiological condition that allows for a reconstruction of the life cycle at the local population scale, but not the abundance of the species, must be regarded as the criterion for the successful existence and breeding of a population in a particular habitat. Such approach really contradicts with the traditional estimation of the community structure of ground beetles. Unfortunately, there are only a few studies on the structure of Carabidae communities which applies the concept of stable-labile components $(12,13,14)$. However, we hope that the current paper will be stimulated similar studies in nearest future.

\section{MATERIAL AND METHODS}

\section{Study area}

Ground beetle communities of nine meadows in the flood-plain of Oka River within the Oka Biosphere Nature Reserve (Ryazan Area, Russia - 54²43'58“N $40^{\circ} 58^{\prime} 42^{\prime \prime} \mathrm{E}$ ) were studied (Fig. 1). Based on inundation time, all model habitats were divided into three groups: high-level meadows (I) never flooded during our study; intermediate meadows (II) characterized by short-term inundations, and low-lying meadows (III) which were flooded for long time periods each year (Fig. 2).

Weather conditions and the inundation regime per habitat in different years of this study are presented in Table 1. Long-term average data on the weather and hy-

Table 1. The weather and hydrological conditions in the middle course of Oka River

\begin{tabular}{|lcccc|}
\hline Weather and hydrological phenomena & 2006 & 2007 & 2008 & Long-term average data \\
\hline Date of snowmelt & $17^{\text {th }}$ April & $21^{\text {st }}$ March & $29^{\text {th }}$ March & $8^{\text {th }}$ April ${ }^{1}$ \\
Sum average temperature from April to October, ${ }^{\circ} \mathrm{C}$ & 2763.4 & 3015.9 & 2903.7 & $2653.6^{1}$ \\
Average monthly temperatures from April to October, ${ }^{\circ} \mathrm{C}$ & 12.9 & 14.1 & 13.5 & $12.4^{1}$ \\
Sum rainfall from April to October, mm & 564.0 & 335.8 & 465.3 & $403.7^{1}$ \\
The maximal level of flood in the Oka River, cm & 570 & 519 & 479 & $557^{2}$ \\
Total duration of flood in the Oka River, days & 39 & 23 & 329 & $33^{2}$ \\
The maximal level of flood in the Pra River, cm & 342 & 329 & $332^{3}$ \\
Total duration of flood in the Pra River, days & 57 & 29 & 47 & $38^{3}$ \\
\hline
\end{tabular}

Notes: 1 - 1938-2010 (15, 17), 2 - 1935-2010 (16, 18), 3-1952-2010 (16, 18). 

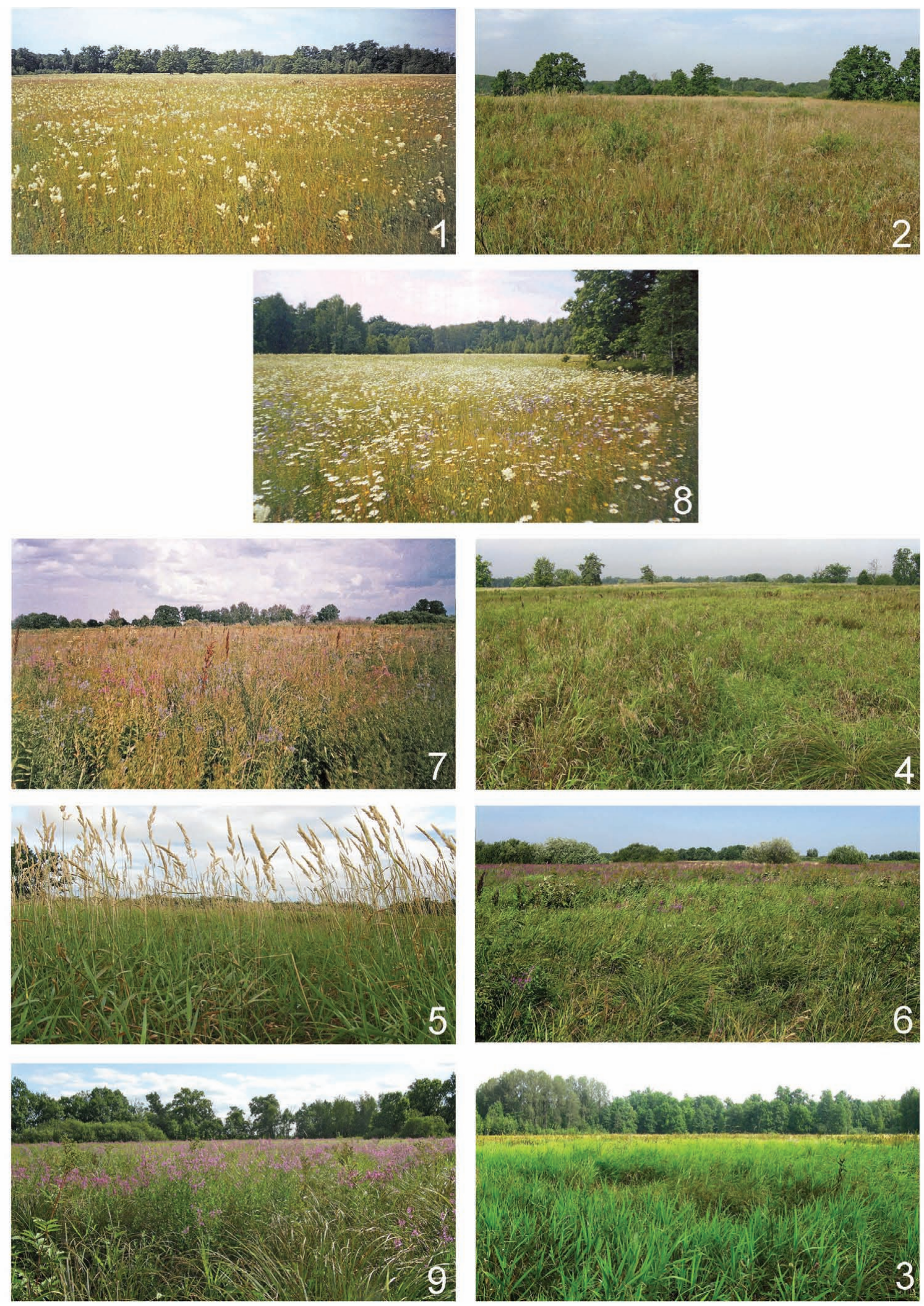

Figure 2. Model habitats: 1 -dry forb-grass meadow, 2 -forb-grass meadow with Carex leporina, 8-grass-forb meadow, 7 - herb meadow with Alopecurus pratense, 4 - wet meadow with Galium boreale and Bromopsis inermis, 5 - sedge-rich meadow with Lythrum virgatum and Digraphis arundinacea, 6-wet sedge-rich meadow, 9-wet meadow with legumes and sedges, 3 - sedge-rich bog meadow (photos by Olga Trushitsyna, 1, 8, 7 - in June 2006; 2-3, 4-6, 9 - in July 2008). 
Table 2. Characteristics of the model habitats

\begin{tabular}{|c|c|c|c|c|c|c|c|c|c|c|}
\hline \multirow{2}{*}{ 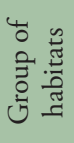 } & \multirow{2}{*}{ 苞 } & \multicolumn{3}{|c|}{$\begin{array}{c}\text { Date of the end of inundation and } \\
\text { the setting of traps }\end{array}$} & \multicolumn{3}{|c|}{$\begin{array}{l}\text { Soil moisture (average for season, } \\
\text { according to Ramensky, 1938) }\end{array}$} & \multicolumn{3}{|c|}{$\begin{array}{c}\text { Maximum projective cover, \% } \\
\text { (according to Braun-Blanquet, 1964) }\end{array}$} \\
\hline & & 2006 & 2007 & 2008 & 2006 & 2007 & 2008 & 2006 & 2007 & 2008 \\
\hline \multirow{3}{*}{ I } & 1 & 22.04 & 02.04 & 01.04 & 2.0 & 1.5 & 1.5 & 40 & 25 & 60 \\
\hline & 2 & 22.04 & 02.04 & 01.04 & 2.5 & 1.5 & 2.0 & 70 & 30 & 80 \\
\hline & 8 & 22.04 & 02.04 & 01.04 & 2.5 & 1.5 & 2.0 & 80 & 45 & 90 \\
\hline \multirow{2}{*}{ II } & 7 & 02.05 & 12.04 & 01.04 & 2.5 & 2.0 & 2.0 & 95 & 100 & 100 \\
\hline & 4 & 12.05 & 12.04 & 01.04 & 3.0 & 2.5 & 3.0 & 100 & 85 & 100 \\
\hline \multirow{4}{*}{ III } & 5 & 22.05 & 12.04 & 11.04 & 3.5 & 2.5 & 3.5 & 100 & 90 & 100 \\
\hline & 6 & 01.06 & 22.04 & 01.05 & 4.0 & 2.5 & 4.0 & 100 & 90 & 95 \\
\hline & 9 & 22.05 & 22.04 & 11.04 & 4.5 & 2.5 & 4.0 & 95 & 90 & 95 \\
\hline & 3 & 21.06 & 12.04 & 01.04 & 5.0 & 3.5 & 4.5 & 100 & 85 & 100 \\
\hline
\end{tabular}

Notes: 1 - dry forb-grass meadow, 2 - forb-grass meadow with Carex leporina, 8 - grass-forb meadow, 7 - herb meadow with Alopecurus pratense, 4 - wet meadow with Galium boreale and Bromopsis inermis, 5 - sedge-rich meadow with Lythrum virgatum and Digraphis arundinacea, 6 - wet sedge-rich meadow, 9 - wet meadow with legumes and sedges, 3 - sedge-rich bog meadow. The meadows are ranked according to soil moisture.

drological conditions follows Onufrenya $(15,16,17,18)$. According to these data, the cool and wet conditions of 2006, with a high and prolonged inundation, was the most typical year as regards the weather and hydrological conditions for the study area, while 2007 and, especially, 2008 were the most atypical, being dry and hot and characterized by low levels and the shortest duration of inundations in the Oka River valley. The temperature in 2008 was more similar to the long-term observation data, but the rainfall sum was considerably higher.

\section{Collecting methods}

Beetles were trapped using plastic pitfall traps of 0.5 1 capacity (Ø $95 \mathrm{~mm}$ ) with $4 \%$ formalin as a fixative. In each habitat, ten traps were arranged along a transect at $10 \mathrm{~m}$ intervals. The traps were set as follows: three at high-level, two at intermediate-level, and four in lowlevel meadows. The traps were checked every ten days, and all captured beetles were dissected for inspection of gonads.

\section{Time of survey}

The traps were set from mid-April to late September 2006 and from early April to late October in 2007 and 2008. The timing of the first sampling was determined by the time of water release and the end of an inundation (Table 2).

\section{Terminology}

Soil moisture was evaluated according to Ramensky's ranks (19), while the projective cover as the relative projected area of the vegetation on the soil surface was estimated following Braun-Blanquet (20).
Based on gonad conditions $(21,22,23)$ and the degree of wear-and-tear of the mandibles $(24,25)$, six physiological states in the adults of both sexes (teneral, immature, mature of parental and ancestral generations, as well as the spent of parental and ancestral generations) were determined (12).

Species with an abundance rate exceeding 5\% were regarded as dominants (26). On the other hand, according to the demographic structure of the local populations three groups of the species were considered as well: residents, migrants and sporadic. In residents, the demographic structure of the local populations is complete, and their habitats are the residential. In migrants and sporadic species, the demographic structure of the local populations is incomplete, and their habitats are the transit. Migrants and sporadic species represent a labile component in ground beetle communities, as opposed to a stable component, represented by residents $(11,12)$.

The typology of the life cycles follows Matalin (27), while that of the communities of soil arthropods follows Kuznetsova (28).

The taxonomy of Carabidae follows the catalogue of Palaearctic Coleoptera (29).

\section{Statistics}

Statistical analyses were performed using STATISTICA 8.0 (30) and PAST 3.10 software (31). The similarities between the assemblages of ground beetles in different types of meadows were calculated using Jaccard's coefficient of community, as well as the Bray-Curtis dissimilarity index. These were followed by clustering using unweighted pair groups with the arithmetic means (UPGMA) method (32). 
Table 3. Abundance (\%) of the dominant species of ground beetles in flood-plain meadows of the Oka River valley.

\begin{tabular}{|c|c|c|c|c|c|c|c|c|c|c|c|c|}
\hline \multirow{3}{*}{ No } & \multirow{3}{*}{ Species } & \multirow{3}{*}{ Years } & \multicolumn{9}{|c|}{ Habitats } & \multirow{3}{*}{$H D$} \\
\hline & & & \multicolumn{3}{|c|}{ I } & \multicolumn{2}{|c|}{ II } & \multicolumn{4}{|c|}{ III } & \\
\hline & & & 1 & 2 & 8 & 7 & 4 & 5 & 6 & 9 & 3 & \\
\hline \multirow{4}{*}{1.} & \multirow{4}{*}{ Carabus granulatus } & 2006 & 0.3 & 6.2 & 10.7 & 9.3 & 14.2 & 13.7 & 12.8 & 16.9 & 5.8 & 8 \\
\hline & & 2007 & 0.2 & 4.6 & 3.3 & 4.6 & 6.3 & 9.1 & 9.2 & 16.6 & 9.4 & 5 \\
\hline & & 2008 & 0.2 & 1.3 & 1.9 & 1.8 & 3.5 & 10.9 & 4.0 & 13.9 & 13.9 & 4 \\
\hline & & 2006 & & & & 0.1 & 1.7 & 4.2 & 5.4 & 2.9 & 0.3 & 1 \\
\hline \multirow[t]{3}{*}{2.} & \multirow[t]{2}{*}{ Clivina fossor } & 2007 & & & & 0.1 & 0.6 & 2.9 & 3.8 & 2.5 & 0.4 & \\
\hline & & 2008 & & & & & 0.1 & 1.3 & 2.8 & 2.9 & 0.2 & \\
\hline & & 2006 & & 2.3 & 0.1 & 0.2 & 0.1 & & 0.2 & & 0.1 & \\
\hline \multirow[t]{3}{*}{3.} & Trechus secalis & 2007 & 0.2 & 0.7 & 0.6 & 0.3 & 0.5 & 0.5 & 0.4 & 0.1 & 6.6 & 1 \\
\hline & & 2008 & 0.2 & 0.3 & 0.9 & 0.1 & 0.3 & 0.4 & 0.3 & 0.2 & 4.9 & \\
\hline & & 2006 & & 2.6 & 0.1 & 0.3 & 5.9 & 6.0 & 6.0 & 1.6 & 5.1 & 4 \\
\hline \multirow[t]{3}{*}{4.} & Bembidion gilvipes & 2007 & & 5.9 & 0.1 & 0.3 & 6.3 & 15.0 & 5.6 & 5.2 & 10.0 & 6 \\
\hline & & 2008 & & 0.4 & 0.1 & 0.2 & 4.9 & 6.1 & 5.8 & 4.8 & 7.9 & 3 \\
\hline & & 2006 & 33.6 & 33.5 & 38.2 & 20.0 & 22.2 & 2.7 & 5.1 & 0.7 & 0.2 & 6 \\
\hline \multirow[t]{3}{*}{5.} & Poecilus versicolor & 2007 & 6.4 & 22.9 & 24.6 & 19.8 & 24.2 & 19.9 & 25.5 & 18.2 & 7.3 & 9 \\
\hline & & 2008 & 5.9 & 52.4 & 9.6 & 31.4 & 22.8 & 21.7 & 25.2 & 14.1 & 5.9 & 9 \\
\hline & & 2006 & 7.0 & 4.6 & 2.0 & 0.4 & & & & & & 1 \\
\hline \multirow[t]{3}{*}{6.} & P. lepidus & 2007 & 6.0 & 3.3 & 3.5 & 0.7 & & & & & & 1 \\
\hline & & 2008 & 7.2 & 6.2 & 8.9 & 0.7 & 0.1 & & & & & 3 \\
\hline & & 2006 & 0.2 & 0.5 & 0.0 & 0.1 & 0.4 & 0.4 & 2.0 & 0.4 & & \\
\hline 7. & Pterostichus vernalis & 2007 & 0.2 & 0.5 & 0.2 & 0.3 & 0.3 & 0.1 & 1.8 & 1.0 & 1.2 & \\
\hline & & 2008 & 0.0 & 0.4 & 0.0 & 0.6 & 0.3 & 0.6 & 5.1 & 1.2 & 1.4 & 1 \\
\hline & & 2006 & 0.7 & 1.0 & 0.3 & 1.4 & 3.3 & 14.4 & 16.6 & 10.6 & 14.9 & 4 \\
\hline 8. & P. anthracinus & 2007 & 1.0 & 1.4 & 1.0 & 2.4 & 0.9 & 2.3 & 1.3 & 4.0 & 4.3 & \\
\hline & & 2008 & 1.0 & 0.7 & 0.5 & 1.3 & 0.6 & 4.3 & 6.8 & 5.6 & 3.9 & 2 \\
\hline & & 2006 & & 0.8 & & 0.2 & 1.0 & 1.5 & 2.4 & 2.3 & 6.9 & 1 \\
\hline 9. & P. nigrita & 2007 & 0.4 & 1.2 & 0.2 & 0.3 & 0.2 & 0.6 & 1.2 & 0.7 & 2.3 & \\
\hline & & 2008 & 0.2 & 0.1 & 0.2 & 0.2 & 0.2 & 0.4 & 2.2 & 0.8 & 3.8 & \\
\hline & & 2006 & 0.2 & 1.0 & 1.9 & 12.0 & 9.0 & 17.7 & 5.2 & 5.7 & 6.2 & 5 \\
\hline 10. & P. melanarius & 2007 & & 0.2 & 1.4 & 32.7 & 23.6 & 17.9 & 18.2 & 28.6 & 16.1 & 5 \\
\hline & & 2008 & & 0.4 & 0.4 & 17.6 & 34.9 & 27.0 & 15.7 & 22.0 & 8.4 & 5 \\
\hline & & 2006 & 2.4 & 0.3 & 0.1 & 0.1 & & & & & & \\
\hline 11. & Calathus fuscipes & 2007 & 15.6 & 0.2 & 0.3 & 0.1 & & & & & & 1 \\
\hline & & 2008 & 18.8 & 0.3 & 2.7 & & & & & & & 1 \\
\hline & & 2006 & 1.6 & 3.3 & 2.0 & 0.9 & 0.4 & & 0.1 & & & \\
\hline 12. & C. melanocephalus & 2007 & 5.6 & 4.7 & 1.9 & 1.6 & 1.5 & 0.6 & 1.6 & 0.2 & 0.6 & 1 \\
\hline & & 2008 & 0.8 & 2.7 & 5.4 & 6.0 & 0.3 & & 2.0 & 0.1 & & 2 \\
\hline & & 2006 & & 0.9 & 0.0 & 0.2 & 0.7 & 1.6 & 8.0 & 23.1 & 10.0 & 3 \\
\hline 13. & Agonum viduum & 2007 & & 0.3 & 0.1 & 0.1 & & 0.1 & 0.6 & 0.9 & 0.5 & \\
\hline & & 2008 & & 0.4 & 0.1 & 0.1 & 0.1 & 1.2 & 1.8 & 4.8 & 1.4 & \\
\hline & & 2006 & & 2.3 & 0.1 & 0.4 & 0.1 & 0.1 & 0.6 & 0.4 & 2.1 & \\
\hline 14. & A. fuliginosum & 2007 & & 6.4 & 0.1 & 0.5 & & 0.1 & 0.3 & 0.6 & 1.3 & 1 \\
\hline & & 2008 & & 2.0 & 0.1 & 0.3 & & 0.1 & 0.2 & 0.2 & 1.3 & \\
\hline & & 2006 & 2.1 & 1.7 & 1.3 & 0.4 & 0.1 & & & & & \\
\hline 15. & Amara equestris & 2007 & 15.8 & 9.6 & 6.9 & 2.1 & & & & & & 3 \\
\hline & & 2008 & 8.8 & 2.4 & 11.4 & 1.6 & & & & & & 2 \\
\hline & & 2006 & 14.6 & 7.1 & 19.3 & 27.0 & 10.5 & 17.5 & 1.6 & 0.8 & 0.7 & 6 \\
\hline 16. & Harpalus rufipes & 2007 & 14.0 & 16.6 & 19.4 & 11.8 & 8.1 & 2.8 & 0.8 & 0.5 & 0.5 & 5 \\
\hline & & 2008 & 20.1 & 11.2 & 20.6 & 12.7 & 7.2 & 1.5 & 0.2 & 0.4 & 0.3 & 5 \\
\hline & & 2006 & 5.7 & 5.2 & 0.4 & & 0.1 & & & & & 2 \\
\hline 17. & H. rubripes & 2007 & 5.6 & 2.1 & 1.3 & 0.2 & 0.1 & & & & 0.1 & 1 \\
\hline & & 2008 & 4.6 & 3.3 & 0.7 & & & & 0.1 & & 0.1 & \\
\hline
\end{tabular}




\begin{tabular}{|c|c|c|c|c|c|c|c|c|c|c|c|c|}
\hline \multirow{3}{*}{18.} & \multirow{3}{*}{ H. latus } & 2006 & 0.8 & 1.8 & 1.6 & 6.4 & 6.6 & 3.5 & 2.4 & 1.0 & 0.7 & 2 \\
\hline & & 2007 & 1.6 & 0.5 & 1.2 & 3.6 & 5.5 & 7.8 & 4.5 & 1.8 & 1.4 & 2 \\
\hline & & 2008 & 1.8 & 0.3 & 8.7 & 5.0 & 4.7 & 3.4 & 1.8 & 3.3 & 0.3 & 2 \\
\hline \multirow{3}{*}{19.} & \multirow{3}{*}{ H. luteicornis } & 2006 & 1.6 & 0.2 & 5.2 & 3.5 & 0.3 & 0.1 & 0.1 & & & 1 \\
\hline & & 2007 & 2.4 & 0.3 & 17.7 & 2.0 & 1.7 & 0.2 & 0.2 & & & 1 \\
\hline & & 2008 & 2.6 & 0.6 & 16.6 & 3.0 & 0.8 & & 0.1 & & & 1 \\
\hline \multirow{3}{*}{20.} & \multirow{3}{*}{ H. smaragdinus } & 2006 & 7.8 & 0.1 & & & & & & & & 1 \\
\hline & & 2007 & 2.4 & & 0.1 & 0.1 & & & & & & \\
\hline & & 2008 & 9.1 & 0.1 & 0.1 & & & & & & & 1 \\
\hline \multirow{3}{*}{21.} & \multirow{3}{*}{ H. affinis } & 2006 & 5.8 & & 1.4 & 0.2 & & & & & & 1 \\
\hline & & 2007 & 2.4 & & 0.8 & 0.1 & & & & & & \\
\hline & & 2008 & 2.7 & 0.1 & 1.2 & & & & & & & \\
\hline \multirow{3}{*}{22.} & \multirow{3}{*}{ Oodes helopioides } & 2006 & & 8.5 & 0.2 & 3.9 & 7.6 & 7.8 & 13.6 & 22.8 & 21.6 & 6 \\
\hline & & 2007 & 0.2 & 3.1 & 0.5 & 2.4 & 4.1 & 3.6 & 4.2 & 8.3 & 12.3 & 2 \\
\hline & & 2008 & & 7.8 & 0.2 & 1.8 & 1.8 & 5.8 & 10.5 & 9.0 & 22.9 & 5 \\
\hline \multirow{3}{*}{\multicolumn{2}{|c|}{ Total dominant species }} & 2006 & 6 & 6 & 4 & 5 & 7 & 6 & 8 & 5 & 6 & \\
\hline & & 2007 & 7 & 5 & 4 & 3 & 6 & 5 & 4 & 5 & 7 & \\
\hline & & 2008 & 6 & 4 & 7 & 5 & 3 & 5 & 6 & 5 & 5 & \\
\hline
\end{tabular}

Notes: bold - dominant species, $H D$ - number of habitats where each species dominated, habitats as in Table 2, groups of habitats as in the above text.

\section{RESULTS}

\section{Species diversity and dominant structure}

During the entire period of observation, more than 52,700 specimens of Carabidae belonging to 142 species were collected. Six genera were characterized by high levels of species diversity, as follows: Amara - 17 species, Harpalus - 13 species, Pterostichus - 12 species, Bembidion - 11 species, Agonum - ten species, and Carabus seven species (Appendix).

The highest species diversity of the genera Amara and Harpalus was observed in the flood-free and short-term inundated meadows, while species of the genus Ophonus were recorded only in the flood free habitat. Mesophilic and meso-xerophilic species of these genera were most diverse and abundant there. Hygrophilous and mesohygrophilous species of the genera Pterostichus, Bembidion, Agonum and Carabus were observed in almost all habitats, but they were abundant only in short- and/or long-term inundated meadows. Species of the genera Agonum were more diverse in long-term inundated meadows.

In dry and short-term inundated meadows 63-89 species were recorded, while 61-67 species were occurred in long-term inundation meadows (Appendix). During different years, 36-69 species were found in each of the study meadows, but only three to eight species prevailed, as a rule. The complex of dominant species included 22 species, comprising $15.5 \%$ of the species diversity and $84 \%$ of the total abundance. However, in different years, the composition of dominant species in the same habitat varied strongly. Eight species, Carabus granulatus, Bembidion gilvipes, Poecilus versicolor, P. lepidus, Pterostichus melanarius, Harpalus rufipes, H. latus and Oodes helopioides, were dominants over all three years of our study, while other species (Agonum viduum, Pterostichus nigrita, Amara equestris, Calathus fuscipes, Harpalus luteicornis etc.) prevailed only in certain years (Table 3).

Some species, such as $P$. versicolor, $C$. granulatus, $P$. melanarius and $H$. rufipes, prevailed in most types of meadows. At the same time, $P$. melanarius was virtually absent from dry meadows, while $H$. rufipes showed a very low abundance in long-term flooded lowland habitats, and only $P$. versicolor dominated in all types of meadow, except in 2006. The meso-xerophilic Harpalus smaragdinus, $H$. rubripes, $H$. luteicornis and $P$. lepidus, as well as the xerophilic $A$. equestris and $C$. fuscipes, were more abundant in permanently dry meadows. However, $H$. luteicornis was affiliated with the dominants only in a grass-forb meadow, while $C$. fuscipes and $H$. smaragdinus were recorded as dominants only in a dry forb-grass one. In wet lowland habitats, the hygrophilous $B$. gilvipes, $P$. nigrita, $P$. vernalis, $P$. anthracinus, $A$. viduum, $A$. fuliginosum and $O$. helopioides were characterized by higher abundance levels, but $P$. nigrita was more abundant only in a sedgerich bog meadow.

\section{Stable-labile components structure}

At the same time, 49 species (35\% of the total species list) were considered as residents, 57 species $(40 \%)$ were recorded only as sporadic, while 36 species $(25 \%)$ were recognized either as sporadic or migrants. All mentioned above 22 dominant species belonged to the assemblage of resident species. It is noteworthy that from three to 27 residents were capable of completing their life cycles at least during one year and at least in one habitat. Among these, only $P$. versicolor was able to reproduce in all habitats during all three years of the study. Two species, $C$. 
granulatus and P. melanarius, completed their life cycles in seven and six habitats, respectively, during the study period. The range of annual variation in the number of residential habitats for individual species owing to changes in air temperature and inundation reached 1.5-3 times (Appendix).

During the three years of the study, in almost all habitats the labile component (migrants and sporadic species) had the highest species diversity, which, however, decreased gradually from permanently dry meadows to long-term inundated ones. The species diversity of the residents increased distinctly, but on average did not exceed $40 \%$ in this series. At the same time, in all meadows during all years, the stable component prevailed and the abundance of residents on average did not fall below 50\%. However, permanently dry meadows were characterized by the highest abundance of the labile component. In certain habitats during different years, the proportion of migrants in the total abundance varied widely from $14.5 \%$ to $56.8 \%$ (Fig. 3).

The dominance structure differed considerably between the full and limited (residents only) species lists for those habitats. For example, in 2007 the community of ground beetles of the dry forb-grass meadow could be recognized as polydominant, in which the abundance of seven species exceeded 5\%. However, among 45 species collected in this habitat, only three were recognized as residents. Thus, this community had to be characterized as oligodominant (Fig. 4A). A similar pattern was observed in our analysis of the carabid community structure of the forb-grass meadows with Carex leporina. In most other study habitats, the structure of Carabidae communities was characterized as polydominat, as distinguished both by the usual criterion of dominance and by the criterion of stable-labile components. Nevertheless, among the dominant species in the ground beetle communities of some permanently dry meadows, as well as some shortterm inundated meadows, one or two migrant species were recorded as well. The aspect of the communities of ground beetles in all long-term inundated meadows, regardless of the approach used, was virtually identical (Fig. 4B).

\section{Community ordination}

A comparative analysis of the results of clustering the carabid communities with consideration of the labile component (complete species lists) and only of residents showed different patterns in several cases.

When using the complete species list for the ordination of communities based on Jaccard's coefficient, habitat vicinity was established first of all. In this case, the adjacent meadows grouped together, as a rule, while the dry forb-grass meadow was not only segregated from all riparian meadows inundated permanently, but also from other dry and short-term inundated habitats (Figs 1, 5A). In contrast, the use of the residents' lists alone (stable component) ensured the grouping of habitats according to their microclimatic conditions, especially the soil moisture and the projective cover (Table 2). The clusters of dry and short-term inundated meadows, on the one hand, and long-term inundated meadows, on the other hand, were clearly separated from each other. At the same time, not the adjacent habitats, but the habitats with similar humidification modes showed the greatest faunal similarity to each other (Figs 1, 5B). Thus, in this case the ordination of communities according to the list of residents alone appeared to be more adequate than that which considered full species lists.

The ordination of the communities of Carabidae based on Bray-Curtis index both for the abundance of all recorded species or resident species only produced the same result. The high abundance of residents in all study habitats, as well as the similar environmental conditions during certain years were the main determinants of Carabidae community similarity of the study habitats.

\section{Long-term dynamics and spatial distribution of stable-labile components}

The proportions of the stable and labile components in all of the habitats studied varied widely over the three years of observation. In 2007, in the ground beetle communities of all non-flooded meadows, as well as of one short-term inundated meadow, the proportion of resident species and their abundance sharply decreased by 14.8 $30.5 \%$. In the communities of carabids of most of the long-term inundated meadows, however, the share of the stable component, as well as its abundance, were virtually invariable and increased only a little $(<10 \%)$. During 2008 , the proportion of resident species, as well as their abundance in dry meadows, reached or, in some habitats, even exceeded the 2006 level. In the long-term inundated meadows, the relative species diversity and abundance of resident species remained unchanged or decreased insignificantly (Appendix).

The annual variations in the abundance of meso-xerophilous species did not exceed 3-3.5 times. These species showed the greatest fidelity to the habitats they occupied and occurred mainly in permanently dry (C. fuscipes, $A$. equestris) or short-term inundated meadows (H. luteicornis). However, even in the favourable, dry and hot years 2007 and 2008, none of these species used wet inundated meadows as a residential habitat; nor did they utilize such places even as transit habitats, despite quite similar soil moisture levels, they shared (Table 2).

Substantial annual fluctuations in abundance, both in residential and transit habitats, were typical of hygrophilous species inhabiting wet long-term inundated meadows. During the coolest and wet season of 2006, the abundance of $P$. anthracinus and $A$. viduum in residential habitats exceeded their abundance in the transit habitats 

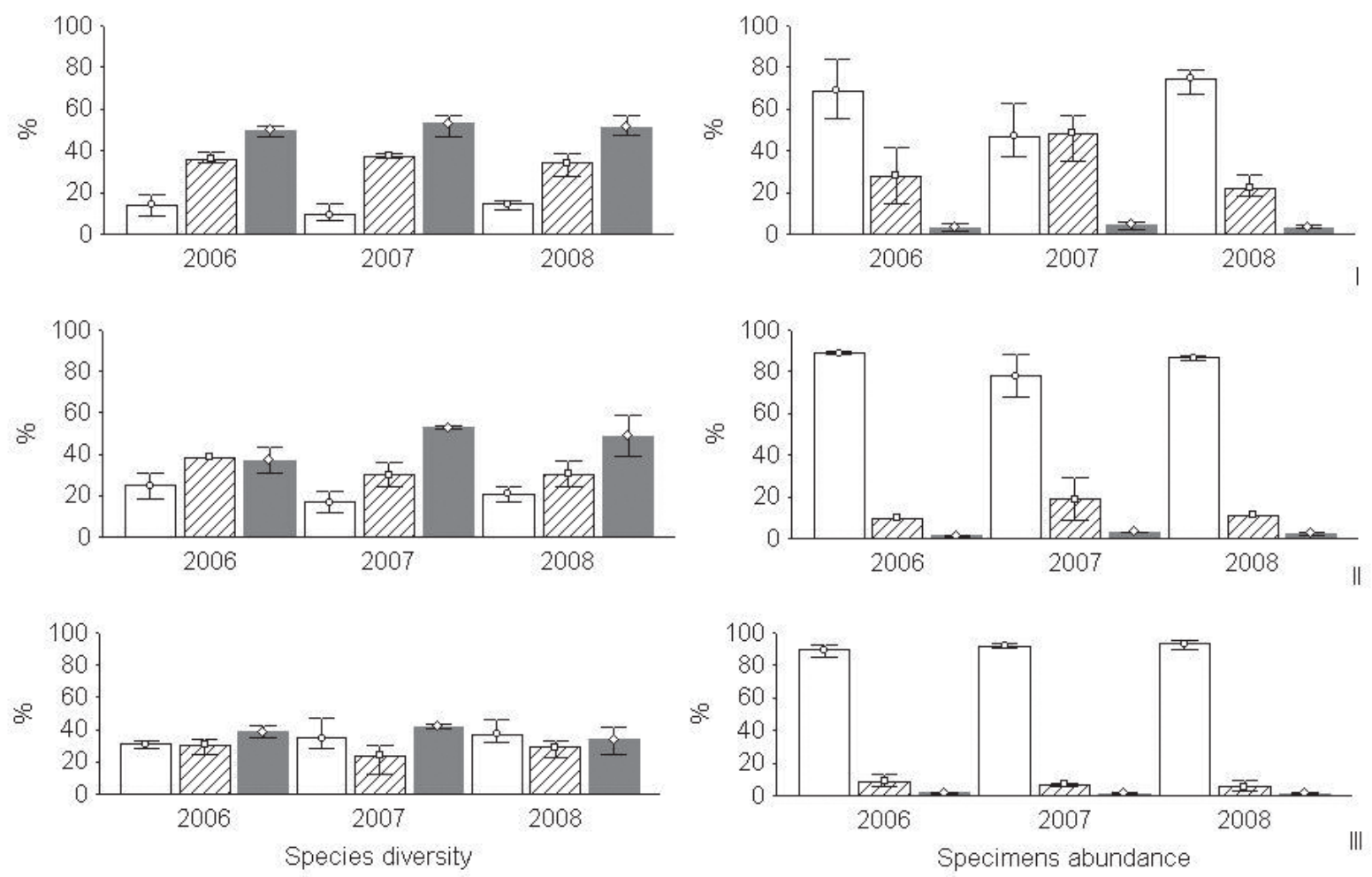

Figure 3. Variations in the proportion of stable and labile components in different groups of flood-plain meadows of the Oka River (white bars - residents, hatched bars - migrants, gray bars - sporadic species, whiskers - SD, groups of habitats as in the above text).
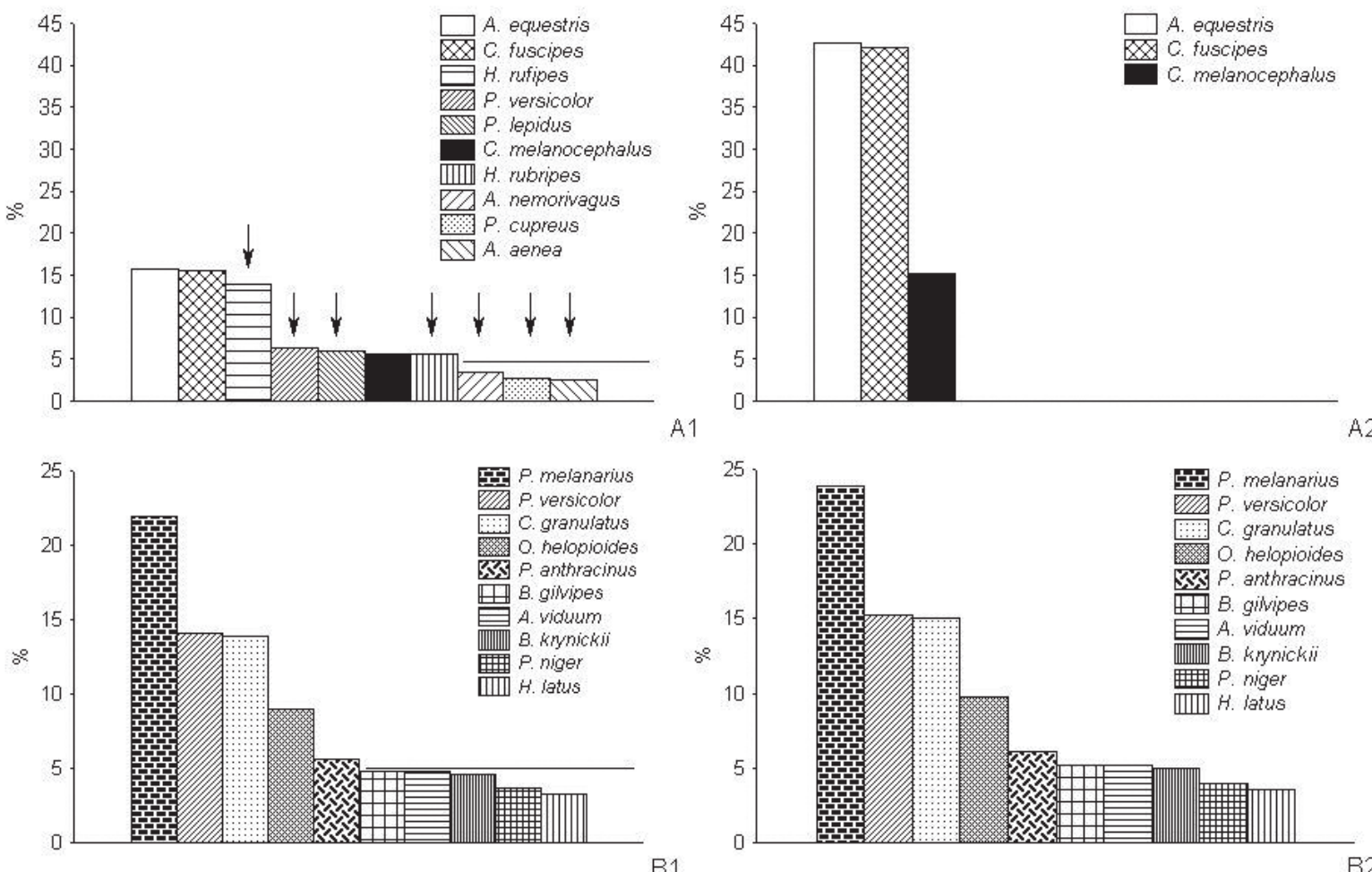

B1

Figure 4. Structure of Carabidae communities of dry forb-grass meadow (A), of wet meadow with legumes and sedges (B), based on the numbers ratio of ten most abundant species (A1 and B1), and the resident species (A2 and B2), A-data for 2007, B-data for 2008 (line delimiting the level of dominants, arrows indicate the migrants). 
more than 16 and 22 times, respectively. However, in the hot and dry 2007, the numbers of each of those species in residential habitats were only 1.5 times higher than in transit ones. During the more favorable 2008, the abundance of both species in residential habitats again exceeded that in transit habitats. At the same time, the total abundance of $P$. anthracinus in 2008 barely exceeded half of the total numbers in 2006, while the abundance of $A$. viduum in 2008 was almost 3.5 times lower than in 2006.

The abundance of eurytopic spring breeders such as $C$. granulatus, $P$. versicolor and $H$. latus remained virtually unchanged over all three years. The high mosaic of soil and vegetation conditions within a relatively small area, as well as their ecological flexibility, allows these species to selectively occupy the most suitable habitats. In the wet year they used some permanently dry meadows as residential habitats, while in the dry years they moved into temporarily flooded lowland places. Due to this reallocation, the abundance of these species in the residential habitats maintained at a high level throughout the three years of research (Appendix).

Last but not least, the abundance of the autumn breeders $P$. melanarius and $H$. rufipes during the three years was remained very high, although it varied considerably under the influence of environmental conditions. Pterostichus melanarius did not use permanently dry meadows for breeding, while even in hot and dry years, $H$. rufipes failed to colonize inundated lowland habitats (Appendix).

\section{DISCUSSION}

The ground beetle fauna of the meadows of the Oka River valley is typical of the flood-plain grasslands of the Central Russian Upland. Most of the species are also known from the neighboring regions e.g. 131 species form the grasslands of the Moscow Area (33, 34), 123 species from the greenlands of the Lipetsk Area (35), 95 species in the meadows of the Bryansk Area (36), 86 species in the grassland of Belarus $(37,38)$, and 75 species in dry and wet meadows of Mordovia (39, 40).

Nevertheless, the species diversity of ground beetles both of the flood-plain as a whole (142 species) and in particular habitats (36-69 species) was higher as compared to other regions of the European part of Russia and of other countries of Europe, e.g.: in the Bryansk Area, 22-56 species have been recorded from wet flood-plain meadows, 18-66 species in dry meadows (41); 56 species in the flood-lands of the Nizhny Novgorod Area, (42); 14-45 species in wet meadows of Mordovia (39, 40, 43), 54-57 species in the flood-plain meadows of the Berezinsky Nature Reserve, Belarus $(37,38)$, from 39 to 45 species in the flood-plain meadows of the Vyatka River, Nurgush Nature Reserve, Russia (44); in the meadows of northern boreal forest in the Arkhangelsk Area, Russia 91 species in various habitats $(45,46,47)$. In Central and
Western Europe, different types of meadow support up to 52 carabid species, as a rule $(48,49,50,51)$. For example, from 7 to 24 species of carabids were recorded during three years in different grasslands of the Limburg Nature Reserve, Germany (7), versus 13 to 43 species in the meadows of the Mazovian Lowland, Poland (6).The high species diversity of Carabidae in the study floodplain meadows can be accounted for by relief heterogeneity and highly mosaic distributions of plant associations. As flat patches alternate with local elevations and wetlands depressions, species with diverse ecological preferences can find suitable habitats. The vicinity of habitats with different soil and vegetation conditions ensure migrations and species turnover; this also increases the species diversity of ground beetles both in general and per particular habitat. In addition, long-term observations and the conservation of undisturbed habitats in the nature reserve also helps in maintaining the high species diversity of ground beetle communities of flood-plain meadows.

At the same time, the composition of dominants in the Carabidae communities of flood-plain meadows of the Oka River fails to differ strongly from similar compositions formed in the meadows within the entire forest zone. As a rule, $P$. versicolor and $P$. melanarius are the most abundant species that prevailed virtually in all types of meadow in Europe (6, 39, 41, 42, 43, 45, 46, 51, 52, 53).

However, neither in all years nor in all study habitats dominant species are characterized by a complete demographic structure. In such cases, despite their high abundance, these species are only to be considered as migrants, while the places they occur in should be regarded as transit habitats (11). Apparently, the community structure drawing a clear difference between the migrants and nonmigrants would differ significantly (Fig. 4A).

From 61 to 89 species were recorded in the studied meadows, but only three to 27 species completed their life cycles during certain years in particular habitats (Appendix). These results correspond well with those of previous studies. In the agricultural landscapes of the Kuban-Azov Lowland, most fields and forest shelter belts were shown to be transit habitats for many carabid species (54). According to the results of our studies, the abundance of the labile component (migrants and sporadic species) in some habitats can be much higher, often even exceeding, the numbers of the stable component, i.e. resident species (9, 11, 12).

It is noteworthy that, in different climatic zones, the proportions of the stable and labile components change in a series of similar habitats. In open flood-plain habitats of the forest zone, the species diversity and abundance of the stable component correlate positively with an increase in soil moisture and projective plant cover. At the same time, the labile component is most diverse in permanently dry meadows, while its abundance averages one-third 

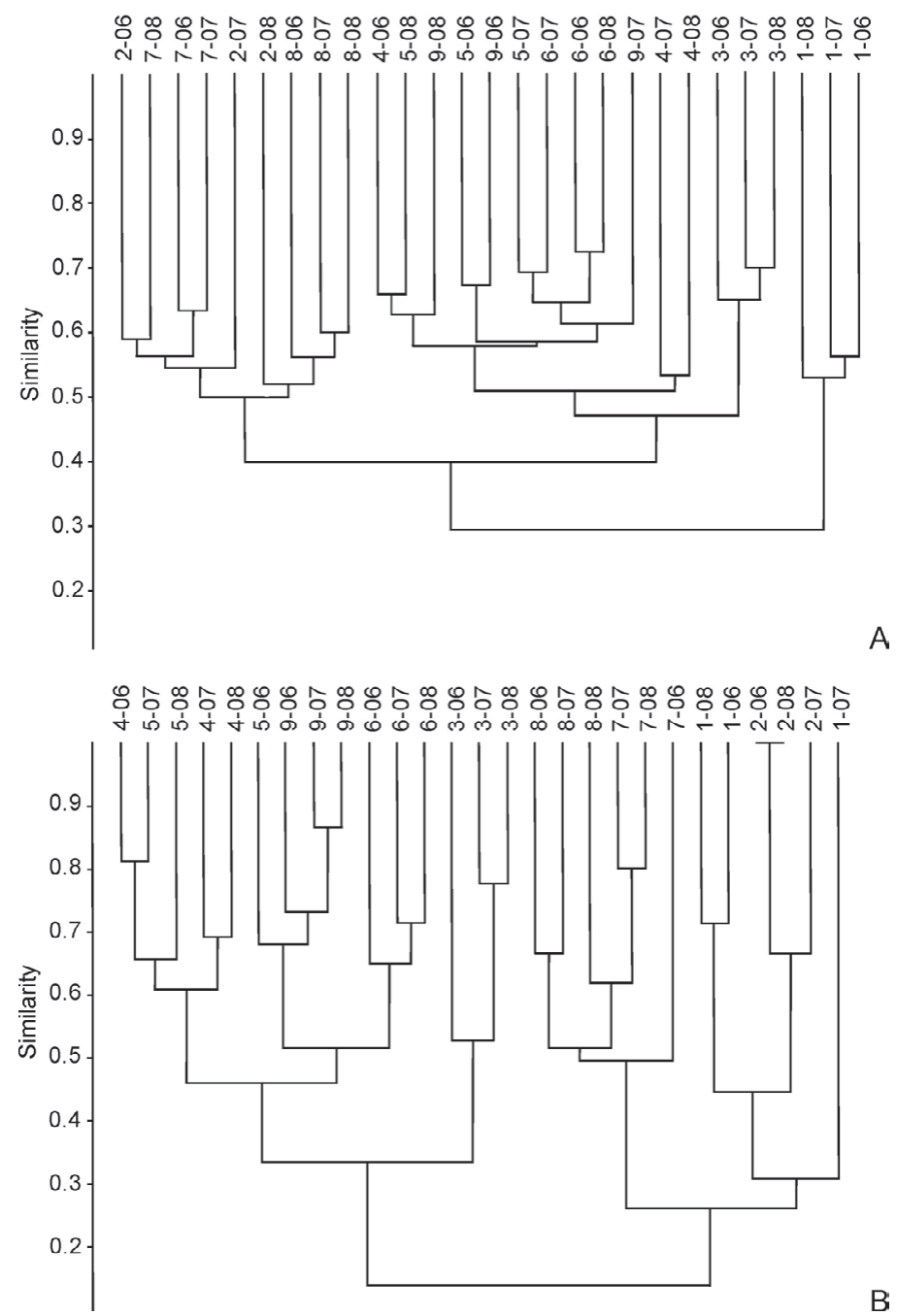

B

Figure 5. Dendrograms of habitat similarity using Jaccard's coefficient, clustered using the UPGMA linkage method with consideration of the labile component (A) and of the residents alone (B). Habitats as in Table 2.

of the total number of specimens (Fig. 6A). In the forest zone, elevations within inundated river flood-lands appear populated by many carabids to escape from, and to survive during the periods of, flooding, also used as their hibernating areas. Thus, the labile component is more diverse and abundant there at the beginning and end of the vegetation season. In the semi-desert zone, the species diversity and abundance of the stable component correlate negatively with habitat moisture. Migrants appear more diverse and abundant in riparian habitats (Fig. 6B). Due to a rather modest contrast between soil temperature and moisture as compared to dry open grasslands, meadow habitats offer relatively favourable conditions even during drier and hotter mid-summer months. As regards floodplains, riparian habitats aid carabid migrations $(11,12)$.

Most species of ground beetles appear randomly distributed in the mosaic of a flood-plain landscape. Some of them inhabit the majority of habitats, while others reproduce only in a few types of meadow with specific soil- vegetation conditions. Annual variations in species diversity and abundance, due to changes in the environmental conditions, result from local migrations within a metapopulation. The abundance of local populations of most of the stenotopic species is determined by their reproductive potential. Due to their narrow ecological ranges, these species are limited in potential habitats, and their residential habitats are few and often fragmentary (55). This increases the risk of their extinction, while a recovery of the abundance and complete demographic structure depends on large-scale migrations. In these cases, variations in abundance under sharp annual changes in the environmental conditions are characterized by maximum amplitudes. This seems to be accounted for both by poor immigrations from the adjacent habitats and poor fecundity rates in the local populations. For example, the abundance of $O$. helopioides both in residential and transit habitats remained virtually constant (Appendix). Nevertheless, a decline of the number of residential habitats 


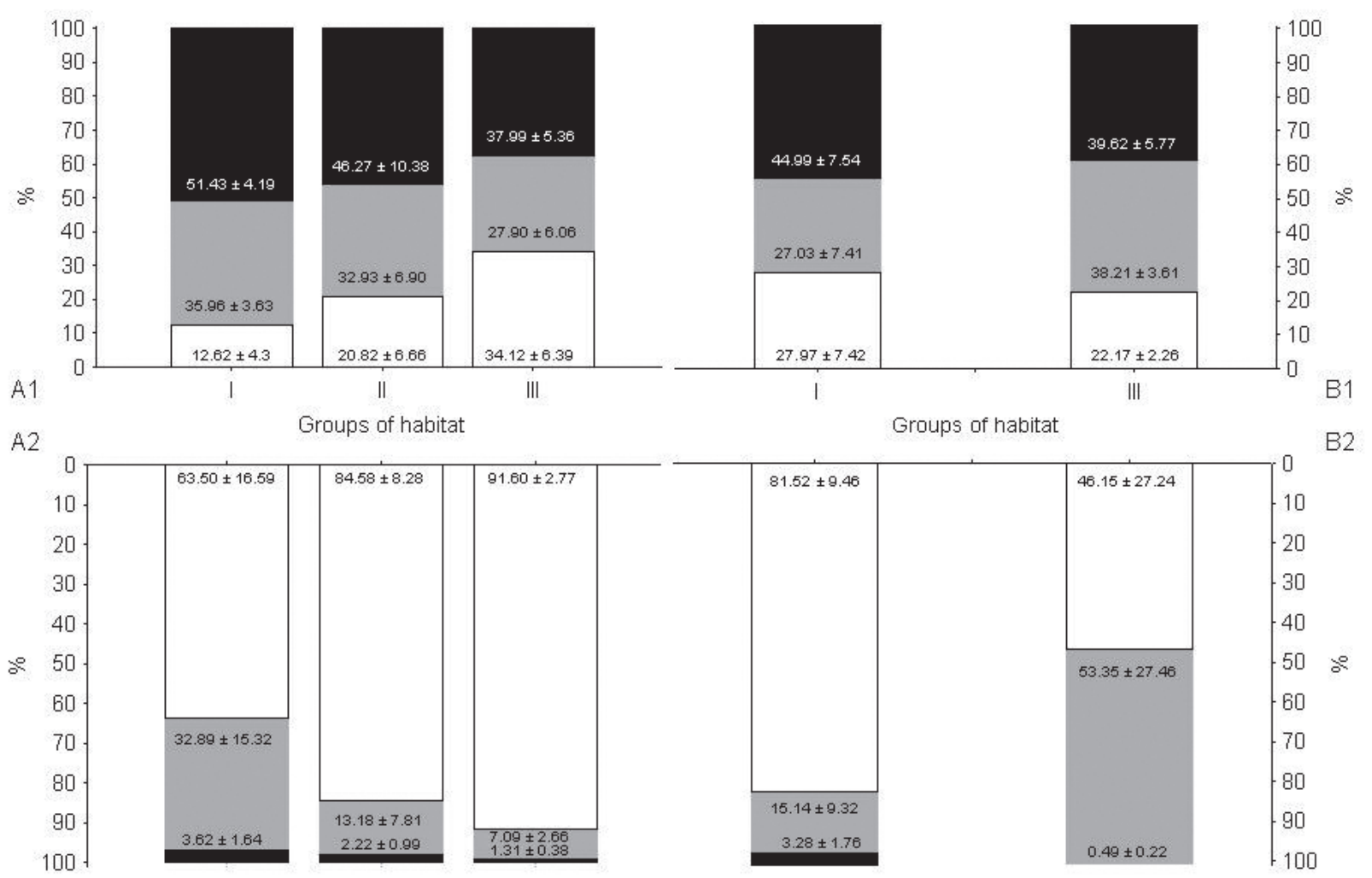

Figure 6. The mean average proportions of stable and labile components in different groups of grassland habitats ( $A-O k a$ River valley, $B-$ Elton Lake region, $A 1, B 1$ - species diversity, A2, B2 - species abundance, white boxes - resident species, grey boxes - migrants, black boxes sporadic species, after \pm the values of $S D$ are given, groups of habitats as in the above text).

during all three years from six to four, and a sharp increase in 2008 in the proportion of females of ancestral generations indicated non-optimal conditions in the local populations of this species. Thus, we believe that the reconstitution of the demographic structure of the local populations of stenotopic species takes place immediately after the living conditions are improved. However, for the recovery of the abundance to the initial population level, at least two, maybe even three years are required.

Eurytopic species are easy to redistribute and occupy all potential habitats available for breeding and development.

Immature and spent specimens of many spring-breeding carabids often move from lowland habitats to permanently dry flood-plain areas for hibernation $(56,57)$. In such habitats, they are recorded at the end or beginning of the vegetation season. At the same time, the abundance of some species (C. granulatus, O. helopioides) can be quite high, dropping to just a few individuals in certain other species ( $P$. anthracinus, $P$. nigrita, some Bembidion). Some species move into dry habitats to escape inundation. For example, the high abundance of $C$. granulatus, B. gilvipes, A. fuliginosum and $O$. helopioides in a dry forb-grass meadow with Carex leporina can be accounted for by the vicinity to lowland habitats. Those species were more numer- ous there only at the beginning of the vegetation season when most of the flood-plain was inundated, with mature specimens also prevailing.

The high abundance of the local populations of some Carabidae species was maintained not only by migrations, but also by life-cycle transformations. All local populations of $P$. melanarius and $H$. rufipes completed their annual life cycle in the cool and wet year 2006. However, in the dry and hot years 2007 and 2008, first facultative and then obligate-biennial life cycles were observed.

In 2006-2007, P. melanarius hibernated mostly as larvae, whereas in 2007 , and especially in 2008 , this species hibernated mostly as immature beetles (10). Thus, its abundance levels in the residential habitats were maintained high throughout the years of our study (Appendix). For $P$. melanarius this seems to be especially important because of its limited migration capacities related to its inability to fly $(58,59,60)$. In $H$. rufipes, after changes in the environment, not only the duration of development was modified, but also the migration activity intensified. In particular, during 2007, seven of the nine flood-plain meadows were transit for this species, while the proportion of migratory specimens generally exceeded $80 \%$. We believe that, under unfavorable environmental conditions, this species is capable of large-scale migrations 
in search of habitats suitable for breeding. This corresponds well with the high migration potential of $H$. rufipes $(58,59,60)$, as well as with the beetles' ability to move over long distances $(11,61)$. The specimens hibernated both as larvae and as immature beetles, belonging to different generations, as a rule. The age heterogeneity of the local populations increases its stability, preventing abrupt changes in abundance and reducing the risk of extinction $(62,63)$.

Acknowledgements: We extend our thanks to all our colleagues at the Oka Biosphere Nature Reserve (Ryazan Area, Russia), especially to Dr. Viktor P. Ivanchev, for their assistance in our work, as well as to Dr. Sergei Golovach (Moscow, Russia) and Dr. Stephen Venn (Helsinki, Finland) who kindly checked the English.

This study was financially supported by the Ministry of Education and Science of the Russian Federation (Project No $\left.1707^{2,3}\right)$.

\section{REFERENCES}

1. NESTERENKO VP 2004 Long-term dynamics of the meadows of Oka Nature Reserve under the influence of the main abiotic processes. Proceed Oka State Biosphere Nat Res 23: 305-314 (in Russian)

2. GRATZER M, RABITSCH W, SCHULZE CH 2013 Impact of flooding on true bug communities (Heteroptera) on meadows of the Morava River flood-plains, Eastern Austria. In: Bauch K (ed.) $5^{\text {th }}$ Symposium for Research in Protected Areas. Conference Volume 5, p 245-250

3. PERSSON VINNERSTEN TZ, ÖSTMAN Ö, SCHÄFER ML, LUNDSTRÖM JO 2014 Insect emergence in relation to floods in wet meadows and swamps in the River Dalälven floodplain. Bulletin of Entomological Research 104(4): 453-461 http://dx.doi. org/10.1017/S0007485314000078

4. JØRUM P 1980 Life cycles and annual activity patterns of Pterostichus melanarius (Illig.) and P. niger (Schall.) (Coleoptera: Carabidae) in a Danish beech wood. Entomol Medd 48(1): 19-25

5. REFSETH D 1986 Phenological adaptation in Patrobus assimilis and $P$. atrorufus (Col., Carabidae). Fauna Norv Ser B 33: 57-63

6. CHECHLOWSKI W 1989 Carabid beetles (Coleoptera, Carabidae) of moist meadow on the Mazovian Lowland. Memorabilia Zool 43: 141-167

7. DEUSCHLE J, GLUCK E 2009(2007) Colonisation and steadiness of carabid beetles in orchards. Bonner Zool Beitr 56(1/2): 7-16

8. TRUSHITSYNA OS 2009a The demographic features of local populations of ground beetles of the genus Carabus L. (Coleoptera, Carabidae) in a mosaic of flood-plain meadows in the south of the Meschera Lowland. Euroasian Entomol J 8(4): 399-410 (in Russian)

9. TRUSHITSYNA OS 2009b The spatio-temporal distribution of two species of the genus Pterostichus (Coleoptera, Carabidae) in a mosaic of flood-plain meadows of the Meschera Lowland. In: Ecology, Evolution and Taxonomy of Animals. Golos Gubernii, Ryazan, p 147-148 (in Russian)

10. TRUSHITSYNA OS, MATALIN AV 2016 Specific features of the life cycle of Pterostichus melanarius (Coleoptera, Carabidae) in a mosaic flood-plain meadows. Entomol Rev 96(2): 144-159 http:// dx.doi.org/10.1134/S0013873816020020

11. MAKAROV KV, MATALIN AV 2009 Ground-beetle communities in the Lake Elton region, southern Russia: a case study of a local fauna (Coleoptera, Carabidae). In: Babenko AB, Matveeva NV, Makarova OL Golovatch SI (eds) Species and Communities in Extreme Environments. Festschrift towards the 75th Anniversary and a Laudatio in Honour of Academician Yuri Ivanovich Chernov. Pensoft Publishers \& KMK, Sofia-Moscow, p 357-384

12. MATALIN AV, MAKAROV KV 2011 Using demographic data to better interpret pitfall trap catches. ZooKeys 100: 3-254 http:// dx.doi.org/10.3897/zookeys.100.1530

13. TRUSHITSYNA OS 2010 The spatio-temporal distribution and the realization of the life cycles of ground beetles (Coleoptera, Carabidae) in the mosaic of flood-plain meadows in the south of the Meschera Lowland. PhD Thesis, Moscow State Pedagogical University Publisher, Moscow, p 1-23 (in Russian)

14. ALEKSANOV VV 2013 The structure of the populations of ground beetles in the urban lands (on the example of Kaluga city). PhD Thesis, Moscow State Pedagogical University Publisher, Moscow, p 1-26 (in Russian)

15. ONUFRENYA MV 2003a Meteorological features of phenological seasons and year periods of the Oka Nature Reserve (19382000). Proc Oka State Biosphere Nat Res 22: 536-585 (in Russian)

16. ONUFRENYA MV 2003b. The hydrological regime of waterbodies of the Oka Nature Reserve (1938-2000). Proc Oka State Biosphere Nat Res 22: 586-620 (in Russian)

17. ONUFRENYA MV 2012a. Meteorological features of phenological seasons and year periods of the Oka Nature Reserve (20012010). Proc Oka State Biosphere Nat Res 27: 392-420 (in Russian)

18. ONUFRENYA MV 2012b. The hydrological regime of water bodies of the Oka Nature Reserve (2001-2010). Proc Oka State Biosphere Nat Res 27: 421-445 (in Russian)

19. RAMENSKY LG 1938 Introduction to a complex of soil geobotanical study of land. Moscow, Selkhozgiz, p.1-620 (in Russian)

20. BRAUN-BLANQUET J 1964 Pflanzensoziologie, Grundzüge der Vegetationskunde. 3. Auflage. Wien, Springer Verlag, s 1-865

21. GILBERT O 1956 The natural histories of four species of Calathus (Coleoptera, Carabidae) living on sand dunes in Anglesey, North Wales. Oikos 7(1): 22-47 http://dx.doi.org/10.2307/3564982

22. VAN HEERDT PF, BLOKHUIS P, VAN HAAFTEN C 1976 The reproductive cycle and age composition of a population of Pteropstichus oblongopunctatus F. in the Netherlands (Coleoptera: Carabidae). Tijdschr entomol 119(1): 1-13

23. WALLIN H 1989 The influence of different age classes on the seasonal activity and reproduction of four medium-sized carabid species inhabiting cereal fields. Holarctic Ecol 12(3): 201-212 http://dx.doi.org/10.1111/j.1600-0587.1989.tb00839.x

24. HOUSTON WWK 1981 The life cycles and age of Carabus glabratus Paykull and C. problematicus Herbst (Col.: Carabidae) on moorland in northern England. Ecol Entomol 6(3): 263-271 http://dx.doi.org/10.1111/j.1365-2311.1981.tb00613.x

25. BUTTERFIELD J 1986 Changes in life-cycle strategies of Carabu problematicus over a range of altitudes in Northern England. Ecol Entomol 11(1): 17-26 http://dx.doi.org/10.1111/j.1365-2311.1986. tb00275.x

26. MOSSAKOWSKI D 1970 Ökologiche Untersuchungen an epigäischen Coleoptere atlantischer Moor- und Heidestandorte. Z Wiss Zool 181(3/4): 233-316

27. MATALIN AV 2007 Typology of Life Cycles of Ground Beetles (Coleoptera, Carabidae) in Western Palaearctic. Entomol Rev 87(8): 947-972 http://dx.doi.org/10.1134/S0013873807080027

28. KUZNETSOVA NA 2005 Communities arrangement in soil springtails. Prometheus, Moscow, p. 1-244 (in Russian)

29. LÖBL I, SMETANA A (Eds) 2003 Catalogue of Palaearctic Coleoptera. Vol. 1. Archostemata - Myxophaga - Adephaga. Appolo Books, Stenstrup, p 1-819 
30. StatSoft Inc. 2013 Electronic Statistics Textbook. Tulsa, OK: StatSoft. WEB: http://www.statsoft.com/textbook/

31. HAMMER $\varnothing$, HARPER DAT, RYAN PD 2001 PAST: Paleontological Statistics Software Package for Education and Data Analysis. Palaeontol Electron 4(1): 1-9

32. BOROVIKOV V 2001 STATISTICA: Computer-Assisted Data Analysis for Professionals. Piter, St. Petersburg, p 1-656 (in Russian)

33. SHAROVA IKh 1982 The fauna of ground beetles (Coleoptera, Carabidae) of the Moscow Area and the level of its study. In: Gilyarov MS (ed) Soil invertebrates of the Moscow Area. Nauka Publisher, Moscow, p 223-236 (in Russian)

34. FEDORENKO DN 1988 The fauna of ground beetles (Coleoptera, Carabidae) of the Moscow Area. In: Rasnitsyn AP (ed) Insects of the Moscow Area: problems of the cadastre and protection. Nauka Publisher, Moscow, p 20-46 (in Russian)

35. TSURIKOV MN 2009 The beetles of the Lipetsk Area. Voronezh University Publisher, Voronezh, p 1-332 (in Russian)

36. BULOKHOVA NA 1995a Ecological and faunistic features of ground beetles (Coleoptera, Carabidae) of grassland ecosystems. In: Suloev AT (ed) Fauna and ecology of Carabidae of the meadows of south-western Russia. Bryansk University Press, Bryansk, p 4-18 (in Russian)

37. SHLYAKHTENOK AS 1991 Ground beetles (Coleoptera, Carabidae) of meadow communities as the object of the ecological monitoring. In: Sushchenya LM (ed) Fauna and ecology of the insects of the Berezinsky Nature Reserve. Urozhdai, Minsk, p 146-169 (in Russian)

38. SOLODOVNIKOV IA 2008 The ground beetles (Coleoptera, Carabidae) of Belarus Poozeriya with the Catalogue of Carabidae of Belarus and adjacent countries. Vitebsk State University Publisher, Vitebsk, p 1-325

39. TIMRALEEV ZA, ARUKOV VA, BARDIN OD 2002 A comparative analysis of the ground beetles (Coleoptera, Carabidae) fauna and population in agroecosystems and meadows of Mordovia. Zool Zh 81(12): 1517-1522 (in Russian)

40. RUCHIN AB, ALEKSEEV SK, ARTAEV ON 2014 Ground beetles (Coleoptera, Carabidae) of the meadows of Mordovia. Young Scient 8(67): 383-387 (in Russian)

41. BULOKHOVA NA 1995b The distribution of ground beetles (Coleoptera, Carabidae) in the plant associations of flood-plain and upland meadows. In: Suloev AT (ed) Fauna and ecology of Carabidae of the meadows of south-western Russia. Bryansk University Press, Bryansk, p 18-37 (in Russian)

42. ANOUFRIEV GA, SHARYGIN GA 1990 Fauna and populations of ground beetles (Coleoptera, Carabidae) in open ecosystems of the Gorky Area. In: Anoufriev G (ed) Terrestrial and aquatic ecosystems. Gorky, p 52-61 (in Russian)

43. FEOKTISTOV VF 1979 Communities of ground beetles in phytocenoses of the Mordovian Nature Reserve. In: Chernova NM (ed) Invertebrate fauna and ecology. Moscow State Pedagogical Institute Publisher, Moscow, p 26-40 (in Russian)

44. TSELISHCHEVA LG 2012 The spatial structure of populations of ground beetles (Coleoptera, Carabidae) in flood-plain communities of the Nurgush Nature Reserve. In: Potemkin NA (ed) Longterm processes in natural complexes of nature reserves of Russia. Tsentralnyi Lesnoi Zapovednik Publisher, Velikie Luki, p 239-244 (in Russian)

45. FILIPPOV BYu, ZEZIN IS 2005 Carabid beetles (Coleoptera, Carabidae) of meadows with karst landscapes of the northern taiga. Vest Pomor Univ Ser Nat Hard Sci 1(7): $72-83$ (in Russian)

46. FILIPPOV BYu, ZEZIN IS 2006 Ecological description of ground beetle communities (Coleoptera, Carabidae) in northern taiga meadows of the Arkhangelsk Region. Biol Bull 33(4): 392-399 http://dx.doi.org/10.1134/S106235900604011X
47. MOKHNATKIN AS, ZEZIN IS, FILIPPOV BYu 2010 Ground beetles (Coleoptera, Carabidae) of different karst landscape biocoenoses of the south-eastern part of Belomor-Kuloi plateau. Vest North (Arctic) Feder Univ Ser Nat Sci 4: 59-64 (in Russian)

48. TIETZE F 1973 Zur Ökologie, Soziologie und Phänologie der Laufkäfer (Col. - Car.) des Grünlades im Süden der DDR. I. Tiel Die Carabiden der untersuchten Lebensorte. Hercynia 10(1):3-76.

49. TIETZE F 1987 Changes in the structure of carabid beetles taxocoenoses in grasslands affected by intensified management and industrial air pollution. Acta Phytopathol Entomol Hun 22(1-4): 305-319

50. LUFF ML, EYRE MD, RUSHTON SP 1989 Classification and ordination of habitats of ground beetles (Coleoptera, Carabidae) in north-east England. J Biogeogr 16(2): 121-130 http://dx.doi. org $/ 10.2307 / 2845086$

51. FUELLHAAS U 2000 Restoration of degraded fen grassland - effects of long-term inundation and water logging on ground beetle populations (Coleoptera, Carabidae). In: Brandmayr P, Lövei GL, Zetto Brandmayr T, Casale A, Vigna Taglianti A (eds) Nature History and Applied Ecology of Carabid Beetles. Pensoft Publishers \& KMK, Sofia-Moscow, p 251-263

52. GRANDCHAMP A-C, BERGAMINI A, STOFER S, NIEMELA R, DUELLI P, SCHEIDEGGER CH 2005 The influence of grassland management on ground beetles (Carabidae, Coleoptera) in Swiss montane meadows. Agric Ecosyst Environ 110: 307-317 http://dx.doi.org/10.1016/j.agee.2005.04.018

53. VENN SJ, KOTZE DJ, LASSILA T, NIEMELÄ JK 2013 Urban dry meadows provide valuable habitat for granivorous and xerophylic carabid beetles. J Insect Conservation. 17(4): 747-764 http:// dx.doi.org/10.1007/s10841-013-9558-8

54. BOKHOVKO EE 2005 The life cycles of ground beetles (Coleoptera, Carabidae) in an agricultural landscape of the south of the Kuban-Azov Lowland. PhD Thesis, Moscow State University Publisher, Moscow, p 1-22 (in Russian)

55. HANSKI I 2005 The shrinking world: ecological consequences of habitat loss. International Ecology Institute Publisher, Oldendorf/ Luhe, Germany, p 1-307

56. LOSHCHEV SM 1990 Hibernation modes in ground beetles (Coleoptera, Carabidae). In: Medvedev GS, Korotyaev BA (Eds) Advances of entomology in the USSR: Coleoptera. Zoological Institute Publisher, Leningrad, p 81-83 (in Russian)

57. ANDERSEN J 2011 Winter quarters of wetland ground beetles (Coleoptera, Carabidae) in South Scandinavia. J Insect Conserv 15:799-810 http://dx.doi.org/10.1007/s10841-011-9378-7

58. DEN BOER PJ 1977 Dispersal power and survival. Carabids in a cultivated countryside (with a mathematical appendix by J. Reddingius). Miscell Papers Landb Hogeschool Wageningen 14: 1-190

59. DESENDER K 2000 Flight muscles development and dispersal in the life cycle of carabid beetles: patterns and processes. Bull Inst Royal Sci Nat Belgique 70: 13-31

60. MATALIN AV 2003 Variations in flight ability with sex and age in ground beetles (Coleoptera, Carabidae) of south-western Moldova. Pedobiol 47(4): 311-319 http://dx.doi.org/10.1078/00314056-00195

61. MATALIN AV 1994 The strategy of dispersal behaviour in some Carabidae species of South-eastern Europe. In: Desender K, Dufrêne M, Loreau M, Luff ML, Maelfait J-P (eds) Carabid Beetles: Ecology and Evolution. Kluwer Academic Publishers, Dordrecht, p 183-188 http://dx.doi.org/10.1007/978-94-017-0968-2_28

62. WEBER F, KLENNER M 1987 Life history phenomena and risk of extinction in a subpopulation of Carabus auronitens. Acta Phytopathol Entomol Hun 22(1-4): 321-328

63. LOREAU M, BEHERA N 1999 Phenotypic diversity and stability of ecosystem processes. Theor Popul Biol 56: 29-47 http://dx.doi.org/10.1006/tpbi.1998.1408 


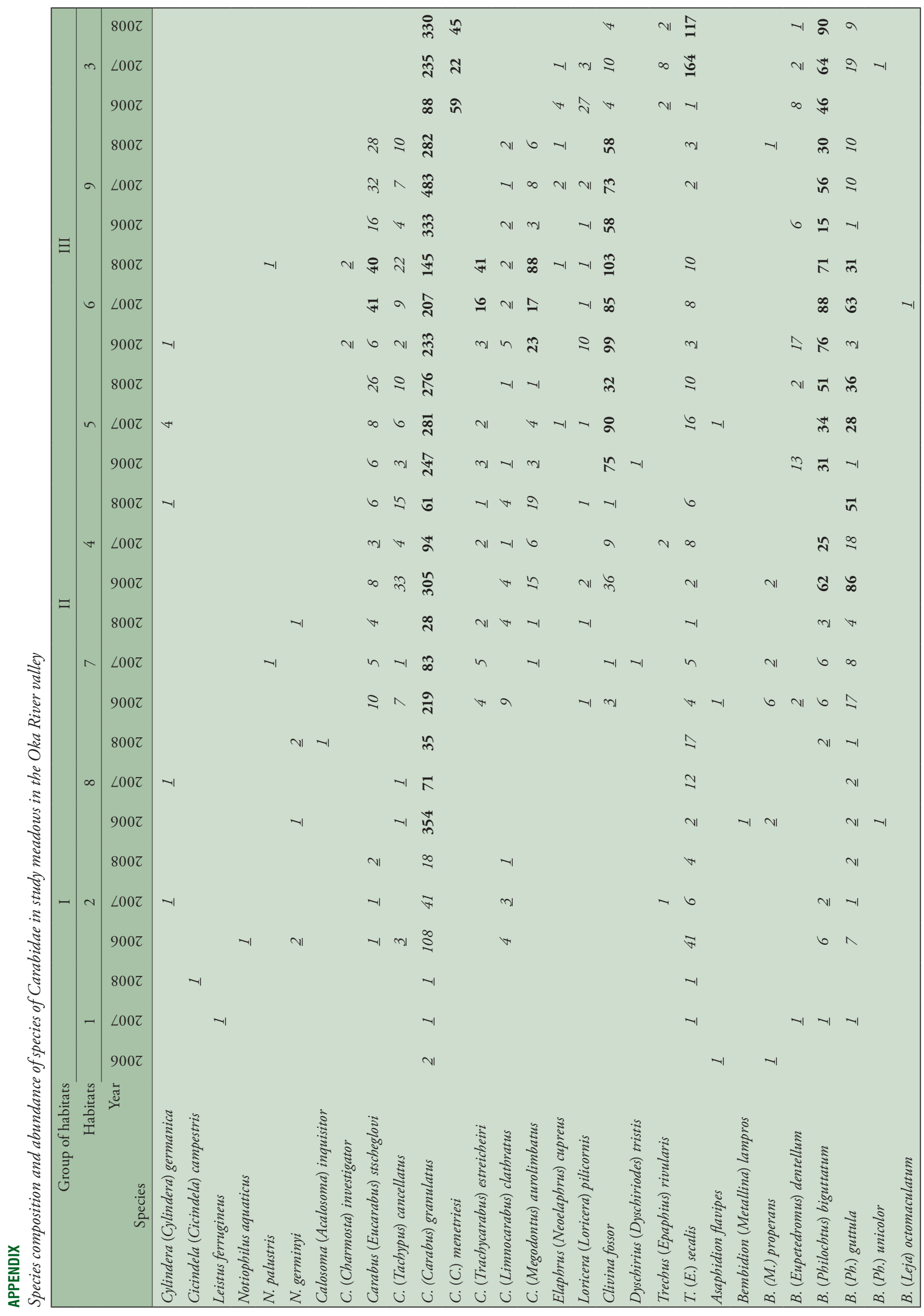




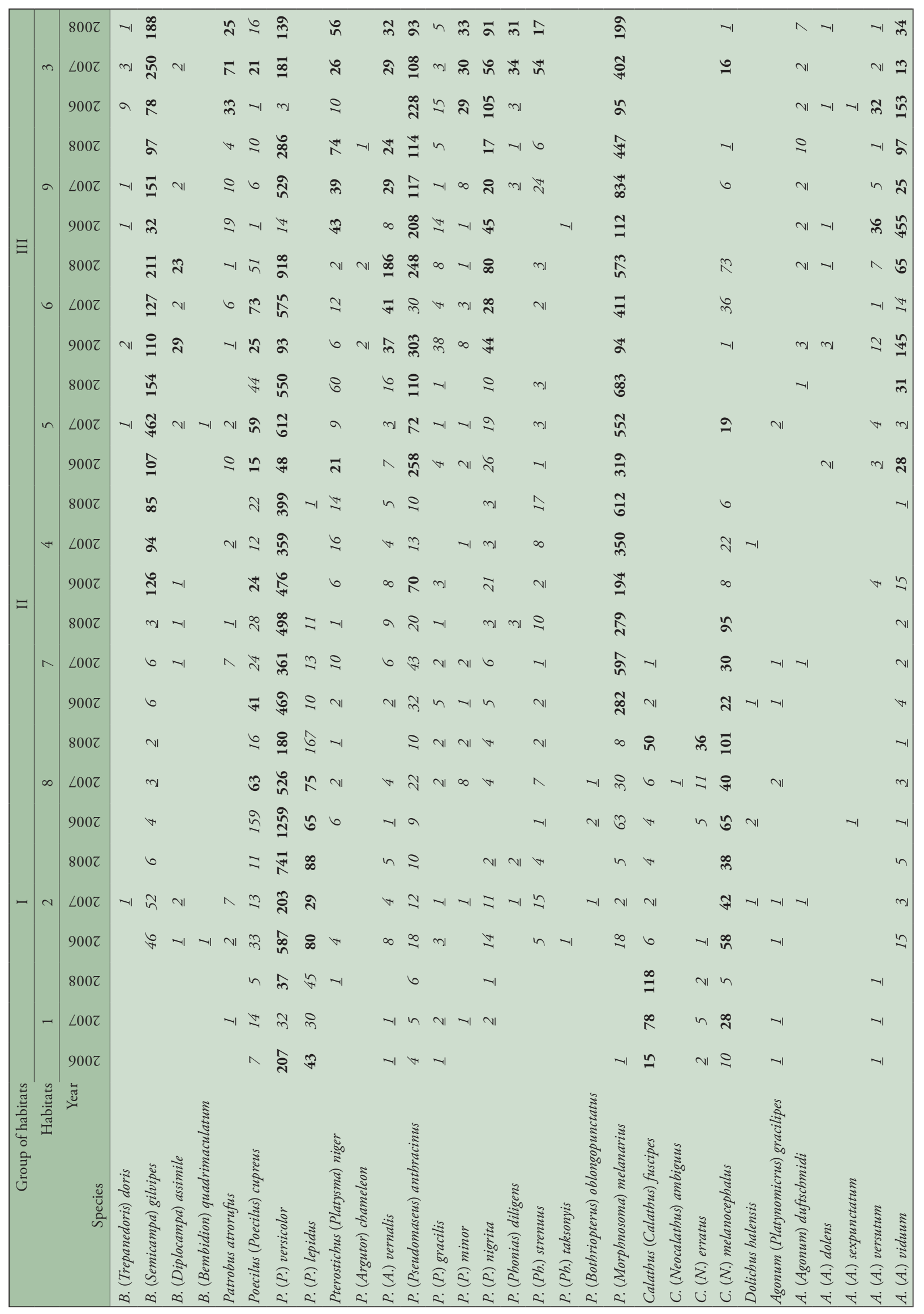




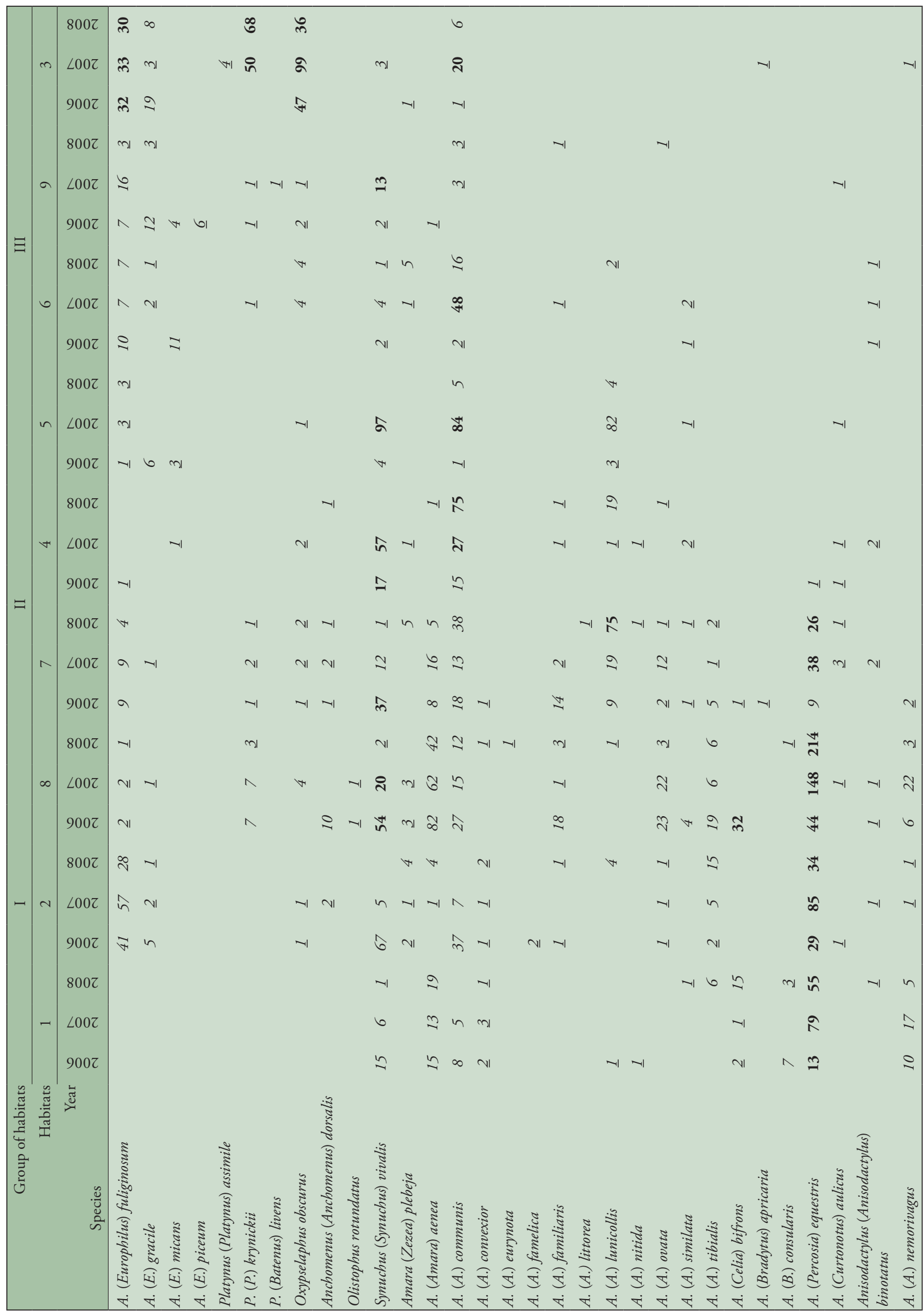




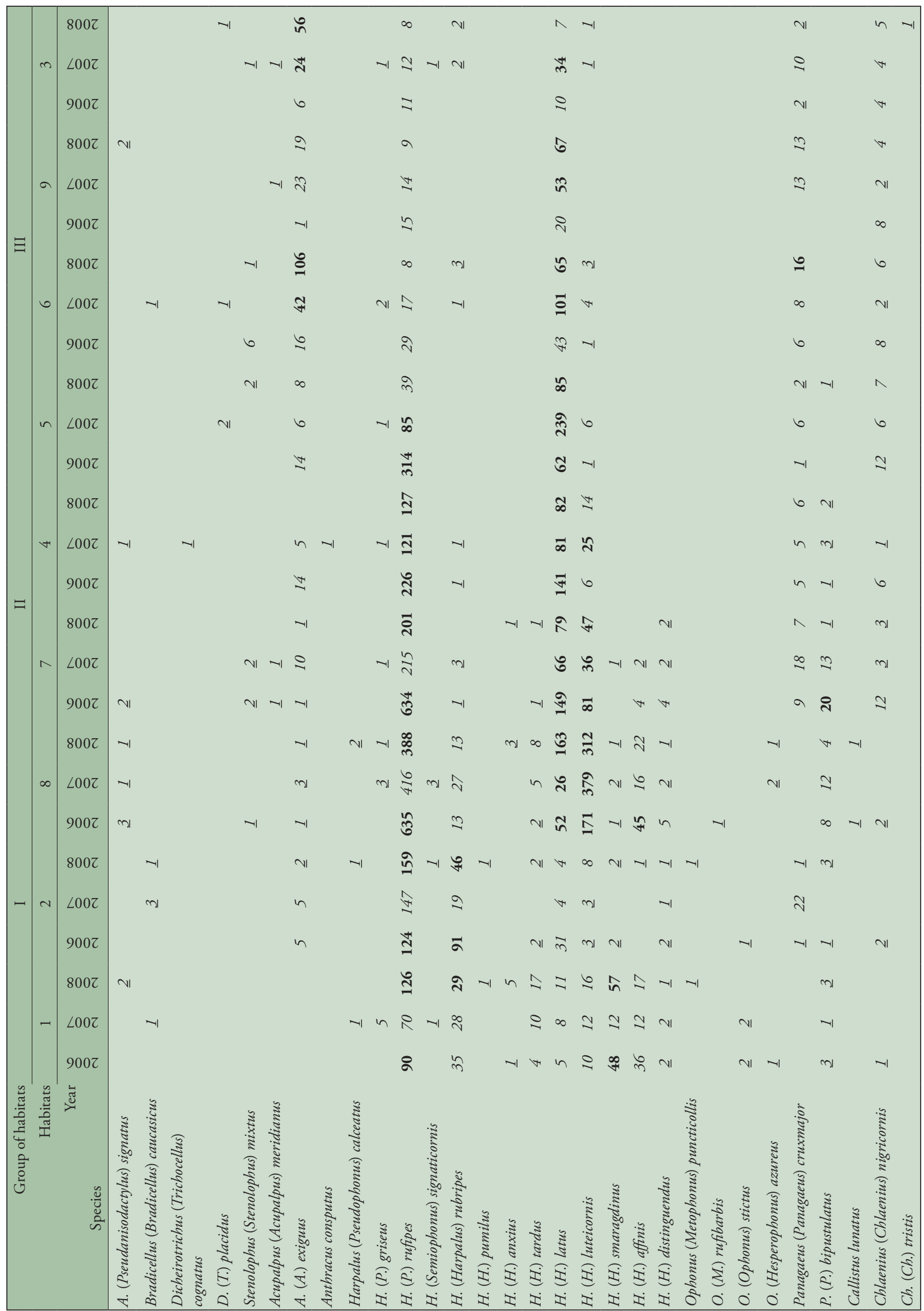




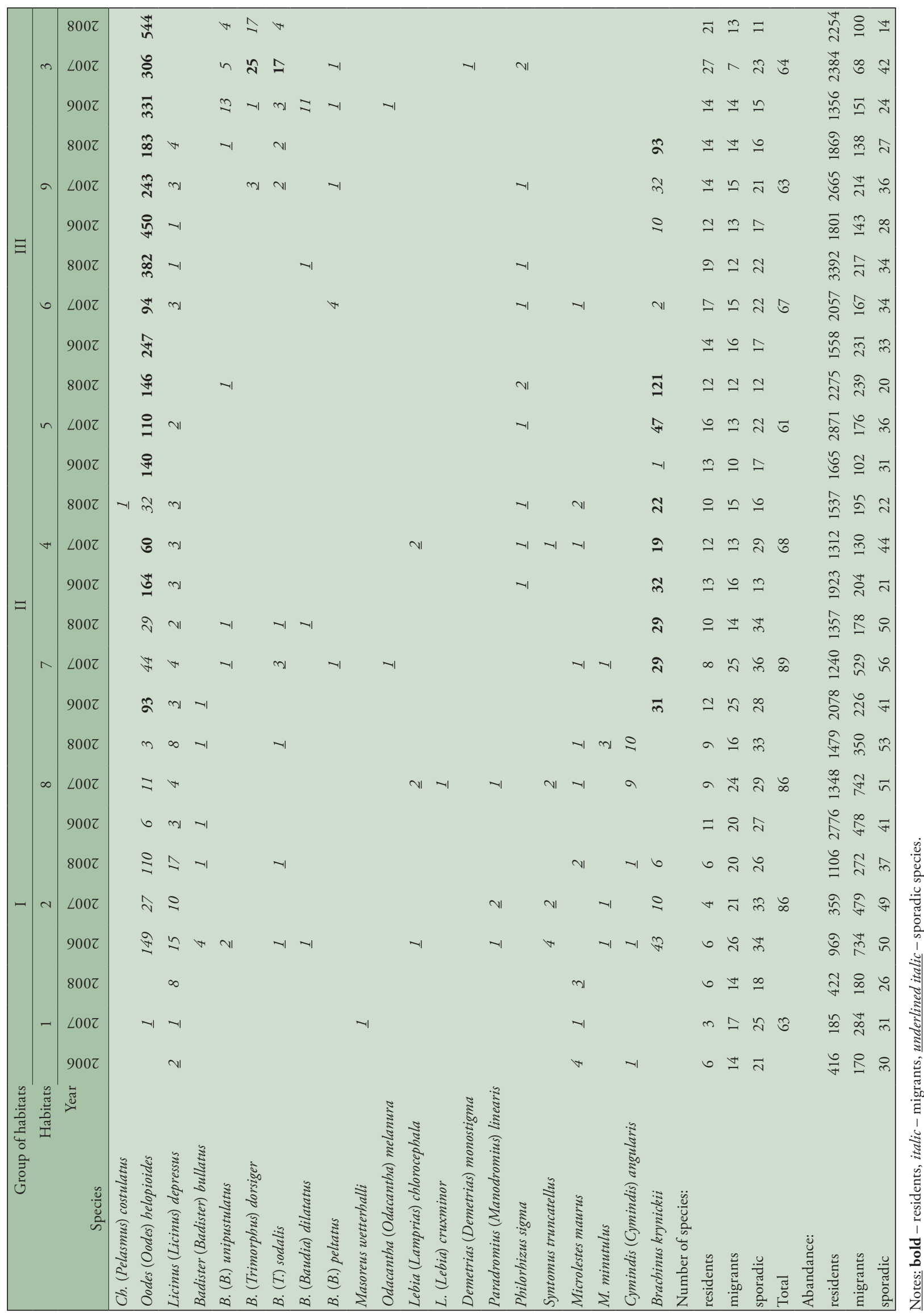

